\title{
PENGUATAN PERAN TOKOH ADAT SEBAGAI PARALEGAL DALAM MEMBERIKAN BANTUAN HUKUM
}

\author{
(Strengthening The Role of Indiginous People's Leader as Paralegal \\ on Legal Aid Programm)
}

\author{
Arfan Faiz Muhlizi \\ Pusat Penyuluhan dan Bantuan Hukum \\ Badan Pembinaan Hukum Nasionaleva \\ JI. Mayjen Sutoyo No.10 Cililitan Jakarta \\ Email:arfan_fm@yahoo.com, arfan.fm@gmail.com
}

Naskah diterima: 1 Maret 2019; revisi: 29 Maret 2019 ; disetujui: 1 April 2019

\begin{abstract}
Abstrak
Penyelesaian perkara nonlitigasi adalah suatu pranata penyelesaian sengketa di luar pengadilan atau dengan cara mengesampingkan penyelesaian secara litigasi. Salah saktu aktor yang bisa didorong untuk menjalankan peran ini adalah paralegal. Meski paralegal bisa menjadi solusi bagi terbukanya akses keadilan yang lebih luas bagi masyarakat adat miskin di daerah terpencil, namun masih perlu dirumuskan beberapa hal teknis seperti bagaimana mengintegrasikan bantuan hukum yang diberikan oleh paralegal yang tumbuh dan telah hidup di komunitas masyarakat adat dengan OBH yang telah terakreditasi, serta bagaimana kualitas bantuan hukum yang diberikan bisa memenuhi standar yang dikendaki oleh kebijakan hukum nasional. Dengan menggunakan pendekatan yuridis normatif dapat disimpulkan bahwa paralegal yang tumbuh dalam komunitas masyarakat adat yang belum terdaftar pada pemberi bantuan hukum (OBH) harus berafiliasi dengan $\mathrm{OBH}$ Terakreditasi sehingga output kegiatannya jadi lebih jelas. Selain itu, jika paralegal komunitas tersebut berafiliasi dengan $\mathrm{OBH}$ Terakreditasi maka paralegal tersebut dapat mengakses dana bantuan hukum yang diberikan melalui $\mathrm{OBH}$ tersebut. Oleh karena itu maka $\mathrm{OBH}$ Terakreditasi perlu terus didorong agar terus-menerus untuk merekrut paralegal komunitas adat, atau terus-menerus membuka diri jika terdapat paralegal yang tumbuh dari komunitas adat berkeinginan untuk berafiliasi agar jangkauan bantuan hukum menjadi lebih luas bagi masyarakat adat melalui jalur non litigasi. Selain itu, paralegal perlu memperoleh pelatihan yang memadai agar memiliki standar kemampuan yang baik untuk memberikan bantuan hukum non litigasi, serta dapat memahami dan mematuhi kode etik internal Pemberi Bantuan Hukum dimana paralegal tersebut terdaftar; dan standar bantuan hukum berdasarkan Undang-Undang Nomor 16 Tahun 2011 tentang Bantuan Hukum.
\end{abstract}

Kata kunci: Paralegal, adat, non litigasi, afiliasi

\begin{abstract}
Settlement of non-litigation cases is an institution for resolving disputes outside the court or by overriding litigation settlement. One of the actors who can be encouraged to carry out this role is paralegals. Even though paralegals can be a solution to open access to wider justice for poor indigenous people in wider areas, some technical matters still need to be formulated such as how to integrate paralegal who grow and have lived in indigenous communities with accredited Legal Aid Organization, and how the quality of legal assistance provided can meet the standards required by national legal policies. Using a normative juridical approach it can be concluded that paralegals who grow up in indigenous communities that have not been registered with legal aid providers must be affiliated with Accredited Legal Aid Organization so that the output of their activities becomes clearer. In addition, if the community paralegal is affiliated with an Accredited OBH, the paralegal can access the legal aid funds provided through the Legal Aid Organization. Therefore, the Accredited Legal Aid Organization needs to be continually encouraged to continually recruit indigenous paralegals, or continually open up if there are paralegals who grow up from indigenous communities who wish to affiliate so that the reach of legal assistance becomes wider for indigenous people through non-litigation channels. In addition, paralegals need adequate training in order to have a good standard of ability to provide non-litigation legal assistance, and can understand and comply with the Legal Aid Provider internal code of ethics where the paralegal is registered; and legal aid standards based on Law Number 16 of 2011 concerning Legal Aid.
\end{abstract}

Keywords: Paralegal, adat, non litigation, afiliation 


\section{A. Pendahuluan}

Kehadiran negara untuk memberikan pengakuan dan perlindungan terhadap masyarakat hukum adat yang sebagian besar pada kondisi termarginalkan dan berada di bawah garis kemiskinan ${ }^{1}$ tidak cukup diberikan di atas kertas. Langkah responsif yang konkrit untuk memberikan perlindungan hukum tersebut adalah dengan memberikan bantuan hukum. $^{2}$ Hal ini merupakan perwujudan konstitusi dimana Negara berkewajiban memenuhi (to fulfil) dan melindungi hak atas bantuan hukum.

Program pendampingan hukum ini dilakukan pemerintah kepada kelompok miskin atau marginal, sebagai wujud kehadiran negara sebagaimana amanat Pasal 28D ayat (1) UndangUndang Dasar Negara Republik Indonesia Tahun 1945, yang menyatakan bahwa "Setiap orang berhak atas pengakuan, jaminan, perlindungan, dan kepastian hukum yang adil serta perlakuan yang sama dihadapan hukum".
Ketentuan konstitusi ini merupakan pijakan dasar yang menjamin hak setiap warga Negara, termasuk orang yang tidak mampu, untuk mendapatkan akses terhadap keadilan agar hak-hak mereka diakui, terjamin, dan dilindungi secara adil. Hal ini kemudian ditindaklanjuti lebih jauh dengan Undang-Undang Nomor 16 Tahun 2011 Tentang Bantuan Hukum. Bantuan Hukum dalam UU ini hanya ditujukan bagi orang miskin atau kelompok marginal. ${ }^{3}$

Secare teknis bantuan hukum ini diberikan oleh Organisasi Bantuan Hukum (OBH) yang telah diverifikasi dan terakreditasi. OBH yang layak sebagai Pemberi Bantuan Hukum dan dapat mengakses anggaran bantuan hukum untuk tahun 2019 hingga 2021 adalah sebanyak $524 \mathrm{OBH}$. Jumlah ini meningkat dibandingkan periode tahun 2013 hingga 2015 yang hanya $310 \mathrm{OBH}$, dan periode 2016 hingga 2018 yang berjumlah $405 \mathrm{OBH}$. Meski demikian, sangat disadari bahwa jumlah $\mathrm{OBH}$ ini belum memadai, apalagi sebarannya masih belum merata di seluruh kantong-kantong kemiskinan.

1 Bappenas, Masyarakat Adat di Indonesia: Menuju Perlindungan Sosial Yang Inklusif, Cetakan I Desember 2013, hlm. 21, Diakses dari https://www.bappenas.go.id/files/7014/2889/4255/ Masyarakat_Adat_di_IndonesiaMenuju_Perlindungan_Sosial_yang_Inklusif.pdf pada 2 Maret 2019.

2 Istilah bantuan hukum sebagai terjemahan dari dua istilah yang berbeda yaitu "legal aid" dan "legal Assistance". "Legal Aid" digunakan untuk menunjukkan pengertian bantuan hukum bagi orang miskin yang tidak mampu membayar advokat. Sedangkan "Legal Assistance" digunakan untuk menunjukkan pengertian bantuan hukum bagi masyarakat mampu dan tidak mampu oleh para Advokat yang mempergunakan honorarium. Dengan kata lain, "legal aid" adalah bantuan hukum dalam arti sempit, sebaliknya "legal assistance" adalah bantuan hukum dalam arti luas. Lebih jauh lihat Todung Mulya Lubis, Bantuan Hukum dan Kemiskinan Struktural, (Jakarta: LP3ES, 1986), hlm. 3. Jaminan atas akses bantuan hukum juga disebutkan secara eksplisit pada Pasal 28G ayat (1), yang menyebutkan bahwa, "Setiap orang berhak atas perlindungan diri pribadi, keluarga, kehormatan, martabat, dan harta benda yang dibawah kekuasaannya, serta berhak atas rasa aman dan perlindungan dari ancaman ketakutan untuk berbuat sesuatu yang merupakan hak asasi“. Hal tersebut semakin dikuatkan pada Pasal $28 \mathrm{H}$ ayat (2), yang menyebutkan bahwa, "Setiap orang berhak mendapat kemudahan dan perlakuan khusus untuk memperoleh kesempatan dan manfaat yang sama guna mencapai persamaan dan keadilan". Secara substantive, hal tersebut di atas, dapat dimaknai bahwa jaminan akses keadilan melalui advokasi hukum dan HAM.

3 Walaupun dalam Undang-Undang Advokat telah ditetapkan kewajiban advokat dalam menangani kasus pro bono yang terkait dengan orang miskin dan tidak mampu, namun dalam kenyataannya tidak cukup banyak advokat yang sungguh-sungguh menangani kasus pro bono tersebut. Lebih jauh mengenai hal ini lihat Hamalatul Qur'ani, Mindset Advokat tentang Probono Harus Diubah, Hukum Online, 24 September 2018, diakses dari https://www. hukumonline.com/ berita/ baca/ lt5ba8e7248fb66/ i-mindset-i-advokat-indonesia-tentang-pro-bono-harusdiubah pada 2 Maret 2019. 
Ada dua konsep pokok dalam bantuan hukum, yaitu konsep bantuan hukum individual dan konsep bantuan hukum struktural. ${ }^{4}$ Konsep bantuan hukum individual (tradisional) pada dasarnya suatu konsep lama yang sejalan dengan sistem hukum yang ada: bantuan hukum pada setiap kasus yang menurut hukum beralasan untuk dibela. Penekannya pada hukum itu sendiri, hukum yang selalu diandaikan netral, sama rasa sama rata. Yang menjadi masalah, cukup sering hukum itu tidak memberikan keadilan. Hukum dalam posisi netral cukup sering justrru menguntungkan mereka yang berkuasa dan berpunya ${ }^{5}$, dan merugikan mayoritas rakyat miskin. Berlawanan dengan itu, konsep bantuan hukum struktural mencoba mengaitkan kegiatan bantuan hukum seperti itu dengan upaya merombak tatanan sosial yang tidak adil. Jadi sasarannya tidak lagi sekedar membantu individual dalam sengketa yang dihadapinya, tetapi lebih mengutamakan sengketa yang punya dampak struktural. Oleh karena itu, bantuan hukum harus dijadikan kekuatan pendorong ke arah tercapainya perombakan tatanan sosial, sehingga akan memiliki pola hubungan yang adil. Dengan demikian hukum akan mampu menjawab tantangan yang dihadapi, dan tidak sekedar mengukuhkan status quo. ${ }^{6}$

Kemampuan negara dalam menyediakan akses atas keadilan secara cepat dan murah bagi masyarakat masih menghadapi berbagai kendala, mulai dari terbatasnya jangkaun aparat negara, hingga terjadinya judicial corruption. ${ }^{7}$ Oleh karena itu perlu mencari alternatif lain dalam rangka mendapatkan akses keadilan. Salah satu alternatif tersebut adalah penguatan mekanisme non litigasi melalui peradilan informal dengan berbagai variannya seperti mediasi dan peradilan adat. Penyelesaian sengketa melalui mekanisme non litigasi ini selaras dengan keberadaan Undang-Undang No.16 Tahun 2011 tentang Bantuan Hukum yang memberikan ruang bagi kemungkinan bantuan hukum melalui mekanisme nonlitigasi. Oleh karena itu Pemerintah masih perlu mendorong agar organisasi bantuan hukum $(\mathrm{OBH})$ memberikan prioritas bantuan hukum terhadap kasus-kasus yang diselesaikan melalui peradilan informal, khususnya peradilan adat agar tidak terjadi penumpukan perkara di peradilan formal.

Dalam Pasal 1 UU Bantuan Hukum disebutkan bahwa Bantuan Hukum adalah jasa hukum yang diberikan oleh Pemberi ${ }^{8}$ Bantuan Hukum secara cuma-cuma kepada Penerima ${ }^{9}$ Bantuan Hukum. Selanjutnya di dalam Pasal 4 UU Bantuan Hukum disebutkan bahwa bantuan Hukum meliputi masalah hukum keperdataan, pidana, dan tata usaha negara baik litigasi maupun nonlitigasi. Penyelesaian perkara nonlitigasi adalah suatu pranata penyelesaian

Todung Mulya Lubis, opcit. hlm. 84-86.

5 Lihat C.J.M.,Schuyt, “Keadilan dan Efektifitas dalam Pembangunan Kesempatan Hidup”, sebagaimana dikutip Ihdi Karim Makinara, Pengaruh Bantuan Hukum Terhadap Masyarakat Miskin, dalam Jurnal Rechtsvinding Volume 2 Nomor 1, April Tahun 2013, hlm.2.

${ }_{6}$ Kritik terhadap tatanan sosial sebagai tidak adil, tidak seimbang, maka kenetralan sama artinya keberpihakan pada tatanan yang ada. Lebih jauh lihat Todung Mulya Lubis, Bantuan Hukum dan Kemiskinan Struktrural, op.cit., hlm. 85.

7 Arfan Faiz Muhlizi, Bantuan Hukum Melalui Mekanisme Nonlitigasi Sebagai Saluran Penguatan Peradilan Informal Bagi Masyarakat Adat, dalam Jurnal Rechtsvinding Volume 2 Nomor 1, April Tahun 2013, hlm.71-73.

8 Pemberi Bantuan Hukum adalah lembaga bantuan hukum atau organisasi kemasyarakatan yang memberi layanan Bantuan Hukum berdasarkan Undang-Undang ini.

9 Penerima Bantuan Hukum adalah orang atau kelompok orang miskin. 
sengketa di luar pengadilan atau dengan cara mengesampingkan penyelesaian secara litigasi dan lebih mengutamakan fungsi mediasi melalui pranata adat di komunitas masyarakat adat setempat. ${ }^{10}$ Salah saktu aktor yang bisa didorong untuk menjalankan peran ini adalah paralegal yang selama ini diemban juga oleh para tokoh adat.

Paralegal adalah seseorang yang secara khusus membantu masyarakat (kaum miskin) dan marjinal, yang karena keterampilan khusus dan memiliki pengetahuan hukum (dasar) serta mampu memberikan pelayanan, pendidikan hukum, dan bimbingan kepada masyarakat. Paralegal juga lazim diartikan sebagai "seseorang yang bukan advokat, namun memiliki pengetahuan dibidang hukum baik hukum materiil maupun hukum acara dengan pengawasan advokat atau organisasi bantuan hukum yang berperan membantu masyarakat pencari keadilan. Paralegal ini bisa bekerja sendiri di dalam komunitasnya atau bekerja untuk organisasi bantuan hukum atau firma hukum". ${ }^{11}$

Dengan demikian hingga saat ini, definisi Paralegal masih belum seragam. Bahkan ada yang masih memandang Paralegal sebagai "Pokrol Bambu". Pokrol Bambu sendiri adalah seseorang yang memberi nasihat hukum tetapi belum memperolah kualifikasi atau pendidikan hukum. Dahulu Pokrol Bambu menjadi aktor penting dalam pelayanan hukum karena masyarakat umum merasa berjarak dengan advokat yang berizin. Paralegal khususnya yang berada di Desa atau komunitas tertentu merupakan garda terdepan dalam penyelesaian masalah di luar pengadilan.

Dalam konteks ini, paralegal diharapkan dapat menjadi jembatan penghubung antara advokat dan komunitas masyarakat miskin diwilayah yang sulit dijangkau oleh advokat. Paralegal yang berasal dari komunitas adat yang memiliki permasalahan hukum yang dipercaya oleh warga masyarakat adat tersebut untuk mewakili kepentingan hukum mereka. Para paralegal tersebut harus memiliki komitmen untuk membantu mencegah dan menyelesaikan masalah hukum dikomunitasnya.

Penguatan peran paralegal ini akan menjadi langkah konkrit bagi misi yang diemban UndangUndang Nomor 16 Tahun 2011 Tentang Bantuan Hukum yang ditindaklanjuti dengan Peraturan Menteri Hukum dan HAM Nomor 1 Tahun 2018 tentang Paralegal dalam Pemberian Bantuan Hukum $^{12}$. Terutama untuk mendukung fungsi Organisasi Bantuan Hukum (OBH) Terakreditasi dan advokatnya yang kondisi sebarannya masih belum ideal dibandingkan jumlah penduduk ${ }^{13}$ dan letak geografis Indonesia. ${ }^{14}$ Oleh karena

10 Dalam pasal (1) angka (10) UU No. 30 Tahun 1999 tentang Arbitrase dan Alternatif Penyelesaian Sengketa, disebutkan bahwa masyarakat dimungkinkan memakai alternatif lain dalam melakukan penyelesaian sengketa. Alternatif tersebut dapat dilakukan dengan cara konsultasi, negosiasi, mediasi, konsiliasi, atau penilaian ahli dan juga dengan penafsiran terbuka bisa ditambahkan pula mekanisme peradilan adat. Lebih jauh lihat Arfan Faiz Muhlizi, opcit, hlm.65.

11 Bandingkan dengan pengertian yang diberikan oleh American Bar Association (ABA), yang memberikan pengertian Paralegal sebagai Legal Assistant, yaitu individu yang telah mengikuti pendidikan, pelatihan atau pengalaman kerja yang mana bekerja sama dengan advokat, kantor hukum/firma hukum, perusahaan, agen pemerintah atau apa saja yang pada khususnya menjadi penerima delegasi tugas pada kerja hukum yang mana menjadi tanggung jawab advokat.

12 Terdapat 2 pasal yang telah di-judicial review Mahkamah Agung, yaitu Pasal 11 dan Pasal 12, yang terkait dengan tidak diperbolehkannya paralegal menangani perkara di pengadilan.

13 Jumlah Penduduk Miskin Indonesia menurut BPS pada tahun 2016 adalah 28.005 .410 orang. Sementara jumlah Organisasi Bantuan Hukum (OBH) yang terakreditasi pada periode 2019 hingga 2021 hanya 524 OBH. Dengan 
itu keberadaan paralegal menjadi sangat penting sebagai rujukan pertama masyarakat, saat berhadapan dengan hukum dan menjadi sumber informasi hukum untuk membantu penyelesaian permasalahan hukum masyarakat berdasarkan kekeluargaan atau musyawarah tanpa selalu berpandangan harus melalui proses peradilan.

Potensi paralegal ini pun secara kuantitatif terus meningkat sebagaimana bisa digambarkan sebagaimana tabel berikut: memenuhi standar yang dikendaki oleh kebijakan hukum nasional.

\section{B. Metode Penelitian}

Berdasarkan permasalahan dan latar belakang di atas, penelitian ini dilakukan dengan menggunakan pendekatan yuridis normatif. ${ }^{15}$ Sebagai suatu penelitian yuridis normatif, maka penelitian ini berbasis pada analisis terhadap norma hukum, baik hukum dalam arti law as it is written in the books

Tabel 1. Perbandingan Jumlah Paralegal 2013-2019

\begin{tabular}{ccccc}
\hline PERIODE AKREDITASI & $\begin{array}{c}\text { JUMLAH } \\
\text { OBH }\end{array}$ & $\begin{array}{c}\text { JUMLAH } \\
\text { KAB/KOTA }\end{array}$ & $\begin{array}{c}\text { JUMLAH } \\
\text { ADVOKAT }\end{array}$ & $\begin{array}{c}\text { JUMLAH } \\
\text { PARALEGA }\end{array}$ \\
\hline $2013-2015$ & 310 & 129 & 1117 & 1018 \\
\hline $2016-2018$ & 405 & 161 & 2070 & 2130 \\
\hline $2019-2021$ & 524 & 215 & 2557 & 2946 \\
\hline
\end{tabular}

Sumber: diolah dari data yang diambil dari https://sidbankum.bphn.go.id yang diakses pada 1 Maret 2019

Meski paralegal bisa menjadi solusi bagi terbukanya akses keadilan yang lebih luas bagi masyarakat adat miskin di daerah terpencil, namun masih perlu dirumuskan beberapa hal teknis terkait: pertama, bagaimana mengintegrasikan bantuan hukum yang diberikan oleh paralegal yang tumbuh dan telah hidup di komunitas masyarakat adat dengan $\mathrm{OBH}$ yang telah terakreditasi; kedua, bagaimana kualitas bantuan hukum yang diberikan bisa and statutes (dalam literatur dan peraturanperundang-undangan). ${ }^{16}$ Referensi juga diperoleh dari dokumen lain yang terkait seperti hasil penelitian sebelumnya, seminar dan/atau lokakarya, buku-buku dan jurnal ilmiah yang terkait, serta data dari berbagai media, baik cetak maupun elektronik. Tradisi penelitian dengan menggunakan laporan media massa, khususnya surat kabar dan internet, semakin berkembang pesat selama beberapa dasawarsa

demikian maka rasio OBH dan penduduk miskin adalah $1: 53.000$. Angka ini masih sangat jauh dari ideal untuk kemudahan akses keadilan.

14 Dari 514 Kabupaten/Kota yang ada di Indonesia, hanya ada 215 Kabupaten/Kota yang memiliki OBH Terakreditasi.

15 Penelitian normatif adalah penelitian yang dilakukan dengan cara meneliti bahan pustaka atau data sekunder belaka. Pemikiran normatif didasarkan pada penelitian yang mencakup (1)asas-asas hukum, (2) sistematik hukum, (3) taraf sinkronisasi vertikal dan horisontal, (4)perbandingan hukum, (5)sejarah hukum. Lebih jauh tentang ini lihat Soerjono Soekanto dan Sri Mamudji, Peranan dan Penggunaan Perpustakaan di Dalam Penelitian Hukum, (Jakarta: Pusat Dokumentasi Hukum Fakultas Hukum Universitas Indonesia, 1979) hlm.15.

16 Lebih jauh lihat Ronald Dworkin, Legal Research, (Daedalus: Spring,1973), hlm. 250. 
terakhir, terutama di bidang kajian tindakan kolektif dan gerakan sosial.

\section{Pembahasan}

\section{Integrasi Paralegal Komunitas Masyarakat Adat Dengan OBH Yang Telah Terakreditasi}

Keberadaan tokoh adat yang berfungsi sebagai paralegal dalam memberikan bantuan hukum pada dasarnya sangat dimungkinkan untuk terus didorong mengingat kualifikasi untuk menjadi paralegal tidak terlalu ketat. ${ }^{17}$ Di samping itu, tata cara penyelesaian sengketa damai telah lama dan biasa dipakai oleh masyarakat Indonesia. ${ }^{18} \mathrm{Hal}$ ini dapat dilihat dari hukum adat yang menempatkan kepala adat sebagai penengah dan memberi putusan adat bagi sengketa di antara warga. ${ }^{19}$

Meskipun demikian dalam Peraturan Menteri Hukum dan HAM Nomor 1 Tahun 2018 tentang Paralegal dalam Pemberian Bantuan
Hukum masih punya kecenderungan untuk mengatur paralegal yang tergabung dalam OBH Terakreditasi saja. ${ }^{20}$ Namun tidak dapat dipungkiri bahwa hukum tidak berkembang pada suatu ruang hampa tetapi berakar dan bertumbuh pada masyarakat tempatnya dilahirkan. Hukum di Indonesia tumbuh dalam kemajemukan identitas (etnik, ras, dan agama) sebagai perekat-bukan pemisahpersatuan nasional. Realitas semacam ini perlu mendapatkan perhatian dari pengelola kebijakan, agar paralegal yang tumbuh dari komunitas adat tetapi belum berafiliasi dengan $\mathrm{OBH}$ Terakreditasi pun lebih mendapatkan perhatian dan pengakuan atas eksistensinya.

Perhatian dan pengakuan terhadap paralegal yang lahir dari komunitas adat ini telah memiliki landasan politik dan konstitusi berupa komitmen negara terhadap kemajemukan. ${ }^{21}$ Komitmen yang kuat pertama-tama nampak pada jaminan penghormatan dan perlindungan terhadap keragaman identitas etnis, agama,

17 Berdasarkan Pasal 4 Peraturan Menteri Hukum dan HAM Nomor 1 Tahun 2018 tentang Paralegal Dalam Pemberian Bantuan Hukum hanya disebutkan bahwa Paralegal wajib memenuhi persyaratan: (1) Warga negara Indonesia; (2) Minimal berusia 18 tahun dan berkewarganegaraan Indonesia; (3) Memiliki pengetahuan tentang advokasi masyarakat "tanpa disebutkan secara eksplisit untuk memiliki gelar sarjana hukum"; dan/atau (4) Memenuhi syarat lain yang ditentukan oleh Pemberi Bantuan Hukum.

18 Ahmadi Hasan, Penyelesaian Sengketa Hukum Berdasarkan Adat Badamai Pada Masyarakat Banjar dalam Kerangka Sistem Hukum Nasional, Disertasi pada Program Doktor Ilmu Hukum Pasasarjana Fakultas Hukum Universitas Islam Indonesia, Yogyakarta, Tahun 2007. Lihat juga Muhammad Koesno, Musyawarah dalam Miriam Budiardjo (Ed), Masalah Kenegaraan, (Jakarta: tanpa penerbit, 1971), hlm. 551.

19 Misalnya di Minangkabau yang bertindak sebagai mediator yang juga mempunyai wewenang untuk memberikan putusan atas perkara yang dibawa kehadapannya adalah sebagai berikut: 1). Tungganai atau mamak kepala waris ada tingkatan rumah gadang, 2). Mamak kepala kaum pada tingkat kaum, 3). Penghulu suku pada tingkat suku, dan 4). Penghulu-penghulu fungsional pada tingkatan nagari. Fungsionmarisntersebut berperan penting dalam menyelesaikan sengketasengketa, baik sebagai penengah dengan (sepadan dengan arbiter atau hakim) atau tanpa kewenangan mamutus (sebagai mediator), Takdir Rahmadi dan Achmad Romsan, Teknik Mediasi Tradisional Dalam Masyarakat Adat Minangkabau, Sumatera Barat dan Masayarakat Adat di Dataran Tinggi, Sumatera Selatan, (Jakarta: Indonesia Center For Environmental Law (ICEL), The Ford Foundation 1997-1998).

20 Lihat Pasal 2 Peraturan Menteri Hukum dan HAM Nomor 1 Tahun 2018 tentang Paralegal Dalam Pemberian Bantuan Hukum, yang menyebutkan bahwa "Paralegal yang diatur dalam Peraturan Menteri ini merupakan Paralegal yang melaksanakan pemberian bantuan hukum dan terdaftar pada Pemberi Bantuan Hukum". Dalam Pasal 5 juga disebutkan bahwa setelah direkrut, paralegal harus terdaftar pada Pemberi Bantuan Hukum, dibuktikan dengan kartu identitas yang disediakan oleh PBH yang berlaku selama maksimum dua tahun dan dapat diperpanjang.

21 Lebih jauh lihat Sunaryati Hartono, Bhinneka Tunggal Ika sebagai Asas Hukum bagi Pembangunan Hukum Nasional, Penerbit Citra Aditya Bakti, Bandung 2006, Bab IV, hlm. 41-65. 
dan budaya yang tertuang dalam UndangUndang Dasar Negara Republik Indonesia Tahun 1945. Penghormatan terhadap satuan-satuan pemerintahan daerah yang bersifat khusus maupun masyarakat hukum adat beserta hakhak tradisionalnya, misalnya, telah dicantumkan secara tegas dalam Pasal 18B ayat (1) dan (2). Jaminan terhadap keadilan sosial juga digariskan secara tegas dalam Pasal 28D ayat (1), (2), dan (3).

Demikian juga jaminan terhadap keragaman identitas agama dan kepercayaan di Indonesia nampak pada Pasal 28E ayat (2) UUD 1945 yang menyatakan bahwa setiap orang berhak atas kebebasan meyakini kepercayaan, menyatakan pikiran dan sikap, sesuai dengan hati nuraninya. Pasal 29 ayat (2) UUD 1945 menegaskan jaminan negara terhadap kemerdekaan tiap-tiap penduduk untuk memeluk agamanya masingmasing dan untuk beribadat menurut agama dan kepercayaannya itu. Pasal 28I huruf (2) kemudian dengan sangat gamblang menyatakan bahwa setiap orang berhak bebas dari perlakuan yang bersifat diskriminatif atas dasar apapun dan berhak mendapat perlindungan terhadap perlakuan yang bersifat diskriminatif itu.

Pada tataran di bawah konstitusi, juga sudah terdapat produk-produk hukum yang menjamin penghormatan dan perlindungan terhadap kemajemukan di Indonesia serta menentang tindakan diskriminatif dalam bentuk apapun. Komitmen ini nyata terlihat dalam beberapa undang-undang seperti Undang-Undang Nomor 39 Tahun 1999 tentang Hak Asasi Manusia,
Undang-Undang Nomor 40 Tahun 2008 tentang Penghapusan Diskriminasi Ras dan Etnis, Undang-Undang Nomor 12 Tahun 2006 tentang Kewarganegaraan, serta Undang-Undang Nomor 12 tahun 2005 tentang Pengesahan International Covenant on Civil and Political Rights (Kovenan Internasional tentang Hak-Hak Sipil dan Politik).

Dalam hal pembentukan peraturan perundang-undangan, Pasal 6 Undang-Undang Nomor 12 Tahun 2011 juga mencantumkan asas kenusantaraan dan asas bhinneka tunggal ika sebagai materi muatan yang harus dicerminkan oleh setiap peraturan perundang-undangan. Saat ini juga tengah dibahas Rancangan UndangUndang Perlindungan Hak-hak Masyarakat Hukum Adat yang diharapkan dapat semakin mengokohkan kemajemukan di Indonesia. Seluruh hal di atas menunjukkan bahwa negara terus berkomitmen untuk menghormati dan melindungi kemajemukan identitas etnis maupun agama di Indonesia. Komitmen inilah yang harus senantiasa kita jaga dan gelorakan sebagai paradigma dalam perumusan dan implementasi kebijakan hukum.

Meski telah terdapat produk-produk hukum yang menunjukkan komitmen negara pada kemajemukan, bukan berarti tidak terdapat tantangan terkait dengan isu ini. Dalam konteks masyarakat majemuk seperti di Indonesia, dinamika yang terjadi di tengah masyarakat baik yang bersifat positif maupun negatif akan senantiasa berpengaruh pada pembentukan kebijakan hukum dari masa ke masa. ${ }^{22}$

22 Mengikuti Alvin Toffler dalam buku "The Third Wave", 1980 yang sekarang telah disusul oleh Mehrtens,cs dengan buku "The Fourth Wave", Masyarakat majemuk memiliki keunikan dan tantangan tersendiri. Kemajemukan yang ada di Indonesia bukan saja karena keragaman etnik, agama, dan budaya, tetapi juga karena bangsa Indonesia adalah "masyarakat dan bangsa yang hidup dalam lima gelombang peradaban sekaligus". Dalam hal ini yang dimaksud dengan Gelombang Pertama adalah masa Peradaban Agraria atau Pertanian, Gelombang Kedua adalah masa Revolusi Industri, Gelombang Ketiga adalah masa Pasca Industri (atau masa Produksi Massal), Gelombang Keempat adalah masa Informasi Global dan Elektronik, dan Gelombang Kelima adalah masa Bio-genetika. 
Perlu disadari bahwa penghormatan terhadap kemajemukan tersebut bukanlah hal yang otomatis ada atau to be taken for granted. la perlu dirawat, dijaga, dan dikembangkan. Apalagi saat ini terjadi eskalasi interaksi antarmasyarakat secara besar-besaran. Interaksi ini dapat bersifat konstruktif (mempererat di satu sisi) tetapi di sisi lain juga dapat bersifat destruktif (merenggangkan). Oleh karena itu perlu berhati-hati dalam menyikapi keragaman hukum. Negara tidak lagi dapat membuat mapping of legal universe, menarik garis batas yang tegas untuk membedakan suatu entitas hukum tertentu dari yang lain, karena sulit untuk menarik batas yang tegas antara hukum internasional, nasional dan lokal, karena sistem hukum yang berasal dari tataran yang berbedabeda itu saling bersentuhan, berinteraksi, berinter-relasi, berpengaruh, menyesuaikan diri dan mengadopsi satu sama lain secara luas. Hal itu sangat kelihatan dari bagaimana hukum internasional bahkan memberi dampak sampai kepada masyarakat lokal dan mendiseminasi nilai-nilai humanitarian, demokrasi, rule of law, dan akuntabilitas internasional. Atau sebaliknya, hukum lokal juga dapat memberi kontribusinya kepada sistem hukum dalam skala internasional atau hukum lokal dari masyarakat lain. Dengan demikian tidaklah cukup untuk sekedar menunjukkan bahwa di lapangan sosial tertentu terdapat keanekaragaman hukum, namun yang lebih penting adalah apakah yang terkandung dalam keanekaragaman hukum tersebut, bagaimanakah sistem-sistem hukum tersebut saling berinteraksi (mempengaruhi) satu sama lain, dan bagaimanakah keberadaan dari sistem-sistem hukum yang beragam itu secara bersama-sama dalam suatu lapangan kajian tertentu. ${ }^{23}$

Dengantidakmengabaikan kebaragaman dan pengakuan atas kebaragaman tersebut, perlu ada mekanisme untuk mengintegrasikannya dalam skema bantuan hukum yang telah berjalan saat ini agar terjadi interaksi yang saling membangun. Untuk dapat saling berinteraksi maka Paralegal yang tumbuh dalam komunitas masyarakat adat belum terdaftar pada pemberi bantuan hukum (OBH) harus berafiliasi dengan $\mathrm{OBH}$ Terakreditasi sehingga output kegiatannya jadi lebih jelas. Selain itu, jika paralegal komunitas tersebut berafiliasi dengan $\mathrm{OBH}$ Terakreditasi maka paralegal tersebut dapat mengakses dana bantuan hukum yang diberikan melalui $\mathrm{OBH}$ tersebut. Oleh karena itu maka OBH Terakreditasi perlu terus didorong agar terus-menerus untuk merekrut paralegal komunitas adat, atau terus-menerus membuka diri jika terdapat paralegal yang tumbuh dari komunitas adat berkeinginan untuk berafiliasi. Dengan demikian maka jangkauan bantuan hukum menjadi lebih luas bagi masyarakat adat melalui jalur non litigasi. Hal tersebut menjadi salah satu cara untuk mengintegrasikan paralegal yag berbasis komunitas adat dengan $\mathrm{OBH}$ yang terakreditasi.

Hal perlu dilakukan mengingat Pasal 2 Peraturan Menteri Hukum dan HAM Nomor 1 Tahun 2018 tentang Paralegal Dalam Pemberian Bantuan Hukum, Paralegal yang dimaksud adalah Paralegal yang melaksanakan pemberian bantuan hukum dan terdaftar pada Pemberi Bantuan Hukum. Oleh karena itu dapat dilakukan kegiatan sertifikasi terhadap Paralegal yang belum terdaftar pada $\mathrm{OBH}$ terakreditasi dengan

23 Benda-Beckmann, Franz von, Changing Legal Pluralism in Indonesia, VI th International Symposium Commission on Folk Law and Legal Pluralism, (Ottawa: 1990), hlm. 2. 
diawali pendidikan dan pelatihan dengan menggunakan kurikulum yang ditentukan oleh Badan Pembinaan Hukum Nasional, yang akan dilaksanakan oleh $\mathrm{OBH}$, Perguruan Tinggi, atau lembaga lain yang bergerak di bidang hukum untuk kemudian didaftar pada $\mathrm{OBH}$ yang telah terakreditasi oleh Kementerian Hukum dan HAM.

\section{Standarisasi Kualitas Bantuan Hukum Paralegal untuk Masyarakat Adat}

Paralegal perlu memperoleh pelatihan yang memadai agar memiliki standar kemampuan yang baik untuk memberikan bantuan hukum non litigasi, ${ }^{24}$ serta dapat memahami dan mematuhi kode etik internal Pemberi Bantuan Hukum dimana paralegal tersebut terdaftar; dan standar bantuan hukum berdasarkan Undang-Undang Nomor 16 Tahun 2011 tentang Bantuan Hukum. ${ }^{25}$

Khusus untuk paralegal yang berasal dari komunitas adat, standarisasi pelayanan bantuan hukum perlu dilakukan bersamaan dengan bimbingan dan pelatihan untuk pembenahan dan pembaharuan administrasi dan manajemen lembaga adat yang melakukan mediasi (seperti peradilan adat) agar mekanisme koordinasi dengan lembaga formal dalam rangka memberikan jaminan kepastian hukum ini dapat berjalan lebih lancar. Pembenahan administrasi peradilan adat dapat digunakan sebagai sarana atau metode untuk menata-ulang administrasi peradilan yang agar lebih efektif, efisien, transparan, aksesibel, bertanggungjawab serta dapat dijadikan sebagai pijakan bagi munculnya tokoh-tokoh adat yang memiliki dedikasi, integritas, serta prestasi yang baik sehingga mampu melahirkan putusan-putusan yang jujur, adil, tidak memihak dan berkualitas. ${ }^{26}$ Beberapa hal teknis yang perlu dilakukan lembaga adat dalam rangka membenahi administrasi dan manajemennya adalah:27

a. Pendokumentasian putusan peradilan adat;

b. Pendokumentasian nilai-nilai adat sekaligus menyelaraskan dengan nilai-nilai HAM dan keadilan universal;

c. Regenerasi pemangku peradilan adat;

d. Pendidikan dan pelatihan masyarakat adat yang ditugaskan membantu pelaksanaan peradilan adat.

Semakin kuatnya peran lembaga adat yang dijalankan oleh para tokoh adat akan semakin memudahkan mekanisme koordinasi antara peradilan adat dengan aparat penegak hukum formal seperti Kepolisian, Kejaksaan dan Pengadilan Negeri. Hal ini dapat bergayung sambut dengan kebijakan yang dikeluarkan lembaga penegak hukum formal. ${ }^{28}$

Selain itu, perlu dikuatkan juga beberapa kompetensi dasar yang perlu dimiliki oleh

24 Lebih jauh mengenai hal ini lihat Pasal 6 ayat (1), Pasal 7 ayat (1), dan Pasal 9 ayat (1) Peraturan Menteri Hukum dan HAM Nomor 1 Tahun 2018 tentang Paralegal Dalam Pemberian Bantuan Hukum, yang menyatakan bahwa Paralegal berhak untuk berpartisipasi dalam sesi pelatihan untuk meningkatkan kualifikasi dan keahlian mereka sebagai pelaksana penyedia bantuan hukum. Pelatihan paralegal dapat diselenggarakan oleh Pemberi Bantuan Hukum; Universitas; Organisasi masyarakat yang menyediakan bantuan hukum; dan/atau Institusi pemerintah, setelah mereka mengajukan proposal pelatihan dan telah disetujui oleh BPHN.

25 Lihat Pasal 15 Peraturan Menteri Hukum dan HAM Nomor 1 Tahun 2018 tentang Paralegal Dalam Pemberian Bantuan Hukum.

26 Bandingkan dengan Ahmad Mujahidin, Peradilan Satu Atap di Indonesia, (Bandung: Refika Aditama, 2007), Hlm.209.

27 Lebih jauh lihat Arfan Faiz Muhlizi, opcit, hlm.75-76.

28 Ibid. 
Paralegal yang diantranya adalah: pertama, kemampuan memahami kondisi wilayah dan kelompok-kelompok kepentingan dalam masyarakat; kedua, kemampuan melakukan penguatan masyarakat dalam memperjuangkan hak asasi manusia, dan hak-hak lain yang dilindungi oleh hukum; dan ketiga, keterampilan mengadvokasi masyarakat berupa pembelaan dan dukungan terhadap masyarakat lemah untuk mendapatkan hak-haknya. ${ }^{29}$

\section{a. Kemampuan Memahami Kondisi Wilayah Dan Kelompok-Kelompok Kepentingan Dalam Masyarakat}

Salah satu materi yang penting untuk dipahami sebagai bagian dari kompetensi dasar paralegaladalahkemampuanmemahamikondisi wilayah dan kelompok-kelompok kepentingan dalam masyarakat. Pemahaman materi ini sangat penting mengingat bahwa masih ada beberapa persepsi mengenai bagaimana hakhak masyarakat hukum adat dan hukum adat ditempatkan dalam tatanan sistem hukum nasional. Sebagai contoh, salah satu bentuk penegasan pengakuan atas hak-hak masyarakat hukum adat adalah dengan diajukannya
RUU Pengakuan dan Perlindungan Hak-hak Masyarakat Hukum Adat (RUU PPHMHA). Hal ini merupakan indikasi diakomodirnya keberadaan hukum adat dalam hukum nasional. ${ }^{30}$ Seiring dengan proses pembahasan RUU PPHMHA, berlangsung juga proses penyusunan dan pembahasan Rancangan Undang-Undang KUHP (RUU KUHP) yang mengakomodasi hukum adat secara lebih tegas agar tidak dipertentangkan dengan asas legalitas. ${ }^{31}$ Asas legalitas merupakan asas yang paling penting dalam hukum pidana. Dari perspektif hukum positif (ius constitutum) asas legalitas diatur dalam ketentuan Pasal 1 ayat (1) KUHP yang merupakan asas legalitas formal. ${ }^{32}$ Pada RUU KUHP, dikaji dari perspektif ius constituendum asas legalitas baik legalitas formal dan legalitas materiil diatur dalam ketentuan Pasal 1 ayat (1) RUU KUHP yang menyatakan: "tidak satu perbuatan pun dapat dikenai sanksi kecuali atas kekuatan peraturan pidana dalam peraturan perundang-undangan yang telah ada sebelum perbuatan dilakukan." Selain itu dipertegas pada ayat (2) bahwa dalam menetapkan adanya tindak pidana dilarang menggunakan analogi. ${ }^{33}$

29 Lihat Pasal 6 Peraturan Menteri Hukum dan HAM Nomor 1 Tahun 2018 tentang Paralegal Dalam Pemberian Bantuan Hukum.

30 Sebelumnya, RUU PPHMHA ini sudah diajukan sejak periode 2010-2014 tetapi gagal disahkan sehingga masuk lagi di Prolegnas Periode 2015-2019.

31 Pada dasarnya asas legalitas lazim disebut juga dengan terminologi "principle of legality", "legaliteitbeginsel", "non-retroaktif", "de la legalite" atau "ex post facto laws".

32 Pada hakikatnya penjatuhan pidana di Indonesia berdasarkan pada Asas legalitas (Nullum Delictum Nulla Poena Siene Pravaelege Poenali) yakni konsepsi Paul Johan Anseln Von Feurbach (1775-1883) sebagaimana termaktub dalam pasal 1 ayat (1) KUHP. Lebih jauh lihat Lieven Dupont dan Raf Verstraeten, Handboek Belgisch Strafrech, Acoo Leuven/Amersfoort, 1990, hlm. 101 dalam: Komariah Emong Sapardjaja, Ajaran Sifat Melawan Hukum Materiel Dalam Hukum Pidana Indonesia Studi Kasus tentang Penerapan dan Perkembangannya Dalam Yurisprudensi, PT Alumni, Bandung, 2002, hlm. 6.

33 Andi Hamzah menyebut bentuk analogi menjadi dua yaitu gesetz analogi yaitu analogi terhadap perbuatan yang sama sekali tidak terdapat dalam ketentuan pidana, dan recht analogi yaitu analogi terhadap perbuatan yang mempunyai kemiripan dengan perbuatan yang dilarang dalam ketentuan hukum pidana. Lebih jauh lihat Andi Hamzah, Perkembangan Hukum Pidana Dalam Era Globalisasi, Asosiasi Pengajar Hukum Pidana dan Kriminologi Indonesia, Perum Percetakan Negara RI, Jakarta, 2008, hlm. 33. Sedangkan M. Cherif Bassiouni, membagi ada tiga katagori analogi. Pertama, analogi untuk menciptakan perbuatan pidana baru yang sudah diduga tetapi 
Dalam ketentuan Pasal 2 RUU KUHP disebutkan bahwa hukum yang hidup dalam masyarakat dapat menentukan seseorang patut dipidana walaupun perbuatan tersebut tidak diatur dalam peraturan perundangundangan. ${ }^{34}$ Meski demikian dipersyaratkan bahwa hukum yang hidup dalam masyarakat tersebut berlaku sepanjang sesuai dengan nilai-nilai yang terkandung dalam Pancasila, UUD NRI Tahun 1945, hak asasi manusia, dan asasasas hukum umum yang diakui masyarakat beradab dan dalam tempat hukum itu hidup. ${ }^{35}$ Lahirnya pengakuan terhadap keberadaan hukum yang hidup di masyarakat (hukum adat) merupakan langkah positif untuk merespon kenyataan hukum di Indonesia yang sebagian masih menggunakan tata cara penyelesaian sengketa secara damai melalui hukum yang hidup di tengah masyarakat mereka sendiri. ${ }^{36}$ Selain Pasal 2, terdapat setidaknya 9 (sembilan) Pasal lain dalam RUU KUHP yang mengatur mengenai pidana adat, yaitu: Pasal 12 ayat (2) yang menyebutkan bahwa untuk dinyatakan sebagai tindak pidana, suatu perbuatan yang diancam pidana oleh peraturan perundangundangan harus juga bersifat melawan hukum atau bertentangan dengan hukum yang hidup dalam masyarakat; Pasal 56 ayat (1) huruf k yang menyebutkan bahwa dalam pemidanaan wajib dipertimbangkan pandangan masyarakat terhadap tindak pidana yang dilakukan;
Pasal 57A huruf g yang menyebutkan bahwa dalam pemidanaan terhadap korporasi wajib dipertimbangkan reaksi masyarakat; Pasal 68 ayat (1) huruf e yang menyebutkan bahwa salah satu pidana tambahan adalah pemenuhan kewajiban adat setempat atau kewajiban menurut hukum yang hidup dalam masyarakat; Pasal 98 ayat (1) yang menyebutkan bahwa pemenuhan kewajiban adat setempat merupakan pidana pokok atau yang diutamakan; Pasal 98 ayat (2) yang menyebutkan bahwa pemenuhan kewajiban adat setempat dianggap sebanding dengan pidana denda Kategori I dan dapat dikenakan pidana pengganti untuk pidana denda, jika kewajiban adat setempat tidak dipenuhi atau tidak dijalani oleh terpidana; Pasal 98B yang menyebutkan bahwa pidana tambahan berupa pemenuhan kewajiban adat setempat dapat dijatuhkan walaupun tidak tercantum dalam perumusan tindak pidana; Pasal 124 huruf b yang menyebutkan bahwa salah satu pidana tambahan adalah pemenuhan kewajiban adat; serta Pasal 141 huruf i yang menyebutkan bahwa salah satu faktor yang memperberat pidana adalah faktor yang bersumber dari hukum yang hidup dalam masyarakat.

Diakuinya hukum yang hidup dalam masyarakat membawa konsekuensi logis bahwa pembentuk RUU KUHP harus menarik hukum tidak tertulis menjadi hukum formal. Hal ini

tidak dirumuskan oleh pembentuk undang-undang. Kedua, analogi yang diterapkan apabila bunyi undangundang tidak cukup jelas atau gagal merumuskan unsur-unsur dari suatu tindak pidana. Ketiga, analogi yang diterapkan terhadap pemidanaan yang tidak didifinisikan oleh pembentuk undang-undang. Lebih jauh lihat M. Cherif Bassiouni, Introduction to International Criminal Law, Transnational Publisher, Inc. Ardsley, New York, 2003, hlm. 179-180.

34 Pasal 2 ayat (1) RUU KUHP menyebutkan "Ketentuan sebagaimana dimaksud dalam Pasal 1 ayat (1) tidak mengurangi berlakunya hukum yang hidup dalam masyarakat yang menentukan bahwa seseorang patut dipidana walaupun perbuatan tersebut tidak diatur dalam peraturan perundangundangan."

35 Pasal 2 ayat (2) RUU KUHP.

36 Muhammad Koesno, Musyawarah dalam Miriam Budiardjo (Ed), Masalah Kenegaraan, (Jakarta: tanpa penerbit, 1971), hlm. 551. 
membuat penegakan hukum yang hidup dalam masyarakat akan dilakukan oleh negara melalui sub sistem peradilan pidana. Dengan adanya dasar hukum yang tegas mengakui eksistensi hukum yang hidup (hukum pidana adat) maka tugas, tanggung jawab dan beban relatif lebih berat kepada aparat penegak hukum, terutama hakim untuk lebih dapat memahami dan menggali nilai-nilai hukum yang hidup dalam masyarakat. Hakim harus benar-benar memahami perasaan masyarakat, keadaan masyarakat, terlebih masyarakat Indonesia yang majemuk dengan pelbagai macam adat istiadat, tradisi dan budaya yang berbeda-beda yang tetap dipertahankan sebagai hukum yang hidup. Soedarto menyebutkan bahwa mata, pikiran dan perasaan hakim harus tajam untuk dapat menangkap apa yang sedang terjadi dalam masyarakat, agar supaya keputusannya tidak kedengaran sumbang. ${ }^{37}$ Hakim dengan seluruh kepribadiannya harus bertanggung jawab atas kebenaran putusannya baik secara formal maupun materiil.

Namun pada sisi lain semangat RUU PPHMHA justru menginginkan adanya peran peradilan informal (lembaga adat) dalam menyelesaikan persoalan hukum yang terjadi di masyarakat adat. Hal ini tentu perlu diharmoniskan agar dapat berjalan beriringan. Selain itu, harmonisasi juga perlu dilakukan RUU PPHMHA terhadap setidaknya 15 UndangUndang dan beberapa peraturan di bawahnya yang berpotensi tumpang tindih dan tidak harmonis.

Selanjutnya, kehadiran negara untuk memberikan pengakuan dan perlindungan terhadap masyarakat hukum adat tidak cukup diberikan di atas kertas sebagai sebuah
Undang-Undang, baik oleh RUU KUHP maupun RUU PPHMHA. Tetapi perlu langkah-langkah konkrit untuk menegakkannya. Hal ini bisa dilakukan dengan mengawali dialog-dialog antar pemangku kepentingan sehingga tidak ada ego sektoral yang mengedepan; menyamakan persepsi dengan Mahkamah Agung selaku salah satu lembaga pemangku kekuasaan kehakiman dalam melihat permasalahan dan mekanisme penyelesaian masalah hukum masyarakat adat; mendorong intensitas koordinasi antara para pemangku peradilan adat dengan institusi formal penegak hukum; serta mendorong sinkronisasi dan harmonisasi norma-norma hukum adat dan peradilan adat dengan hukum nasional.

Seiring dengan proses tersebut, untuk dapat memahami dan menggali nilai-nilai hukum yang hidup dalam masyarakat, maka hakim perlu dibantu oleh sebuah panduan praktis berupa modul atau kompilasi hukum adat agar pemahaman dan penggalian hukum adat untuk diterapkan dalam putusan dapat berlangsung lebih cepat dan mengandung kepastian hukum. Oleh karena itu maka perlu untuk segera menyusun modul atau Kompilasi Hukum Adat yang sesuai dengan ketentuan Pasal 2 ayat (2) RUU KUHP, yaitu: pertama, nyata-nyata hidup dalam masyarakat; kedua, sesuai dengan nilainilai yang terkandung dalam Pancasila; ketiga, sesuai dengan UUD NRI Tahun 1945; keempat, selaras dengan hak asasi manusia; dan kelima, selaras dengan asas-asas hukum umum yang diakui masyarakat beradab. Kompilasi ini pada dasarnya merupakan sekaligus re-identifikasi hukum adat dan verifikasi terhadap hukum nasional.

\footnotetext{
Soedarto, Hukum dan Hukum Pidana, (Bandung: PT Alumni, 1983), hlm. 81
} 


\section{b. Penguatan Masyarakat Dalam Memperjuangkan Hak Asasi Manusia, Dan Hak-Hak Lain Yang Dilindungi Oleh Hukum}

Pasal 1 ayat (3) UUD NRI 1945 secara tegas menyatakan: "Negara Indonesia adalah negara hukum." Negara hukum yang dimaksud dalam ketentuan Pasal 1 ayat (3) UUD UUD NRI 1945 adalah negara yang menegakkan supremasi hukum untuk mewujudkan kebenaran dan keadilan, di mana di dalamnya tidak ada kekuasaan yang tidak dapat dipertanggungjawabkan. Negara Hukum Indonesia diilhami oleh ide dasar rechtsstaat dan rule of law. Oleh karena itu maka Negara Hukum Indonesia memiliki elemen yang terkandung dalam konsep rechtsstaat maupun dalam konsep rule of law. ${ }^{38}$

Dalam rechtsstaat, dasar kewibawaan kenegaraan (de grondslag van statelijk gezag) diletakkan pada hukum dan penyelenggaraan kewibawaan kenegaraan dalam segala bentuknya ditempat dibawah kekuasaan hukum. Rechtsstaat mengandung unsur-unsur persamaan di depan hukum, dapatnya setiap orang mempertahankan diri dalam semua situasi yang layak, adanya kesempatan yang sama bagi warga negara yang berhak untuk mencapai semua jabatan kenegaraan, dan adanya kebebasan pribadi bagi warga negara. Menurut Julius Stahl, konsep Negara Hukum yang disebutnya dengan istilah 'rechtsstaat' itu mencakup empat elemen penting, yaitu: ${ }^{39}$ (1) Perlindungan hak asasi manusia; (2) Pembagian kekuasaan; (3) Pemerintahan berdasarkan undang-undang; dan (4) Peradilan tata usaha Negara.

Sedangkan "Rule of Law" sejak awal telah membedakan formalita aturan hukum yang tertulis dengan cakupan nilai keadilan yang dikandungnya. Bahkan di Inggris berkembang istilah " the rule of law and not of a man" versus istilah "the rule by law" yang berarti "the rule of man by law". Dalam istilah "the rule of law" terkandung makna pemerintahan oleh hukum, tetapi bukan dalam artinya yang formal, melainkan mencakup pula nilai-nilai keadilan yang terkandung di dalamnya. Karena itu, digunakan juga istilah " the rule of just law". Dalam istilah "the rule of law and not of man", dimaksudkan untuk menegaskan bahwa pada hakikatnya pemerintahan suatu negara hukum modern itu dilakukan oleh hukum, bukan oleh orang. Istilah sebaliknya adalah "the rule by law" yang dimaksudkan sebagai pemerintahan oleh orang yang menggunakan hukum sekedar sebagai alat kekuasaan belaka. A.V. Dicey menguraikan adanya tiga ciri penting dalam setiap Negara Hukum yang disebutnya dengan istilah "The Rule of Law", yaitu: ${ }^{40}$ (1) Supremacy of Law; (2) Equality before the law; dan (3) Due Process of Law.

Dari kedua konsep ini terlihat bahwa terdapat persamaan dan perbedaan konsep rechtsstaat dengan konsep rule of law. Persamaan tersebut adalah: pada dasarnya kedua konsep itu mengarahkan dirinya pada satu sasaran yang utama, yakni pengakuan dan perlindungan terhadap hak-hak asasi manusia. Indonesia mengakomodir kedua konsep ini

\footnotetext{
38 Jimly Asshiddiqie, Gagasan Negara Hukum Indonesia, Disampaikan dalam Forum Dialog Perencanaan Pembangunan Hukum Nasional yang diselenggarakan oleh Badan Pembinaan Hukum Nasional Kementerian Hukum dan HAM Rl pada tanggal 22-24 Nopember 2011 di Jakarta.

39 Ibid.

40 Ibid.
} 
dan melahirkan sebuah konsep Negara hukum tersendiri. Negara hukum Indonesia memiliki ciri-ciri khas Indonesia karena Pancasila harus diangkat sebagai dasar pokok dan sumber dari segala sumber hukum. Oleh karena itu maka negara hukum Indonesia dapat pula dinamakan negara hukum Pancasila. Dari pandangan di atas, terlihat bahwa meskipun dalam penjelasan UUD 1945 digunakan istilah rechtsstaat, namun konsep rechtsstaat yang dianut oleh negara Indonesia bukan konsep negara hukum Barat (Eropa Kontinental) dan bukan pula konsep rule of law dari Anglo-Saxon, melainkan konsep negara hukum Pancasila. Ciri khas Negara Hukum Pancasila adalah dibandingkan dengan rechtsstaat maupun rule of law adalah terdapat elemen (1) Berketuhanan YME; (2) Gotong Royong; (3) Bhineka Tunggal Ika; serta (4) Demokrasi.

Dalam konteks Indonesia, tidak bisa tidak, kita perlu memiliki tonggak dasar pemikiran yang kuat, nilai-nilai yang akan semakin mengokohkan identitasnasional kita sebagai suatu bangsa, yaitu Pancasila. Arah pembangunan hukum bukanlah sesuatu yang dapat berdiri sendiri, melainkan terintegrasi dan memerlukan penyelarasan dengan garis-garis besar gagasan dalam UUD NRI Tahun 1945. Hukum perlu memastikan bahwa pembangunan dapat harmonis dengan tuntutan global seperti saat ini, namun tidak meninggalkan nilai-nilai kebangsaan Indonesia. Hal ini sejalan dengan visi pemerintah saat ini yang ingin meyakinkan kepada bangsa Indonesia melalui semangat "Meneguhkan Kembali Jalan Ideologis", yaitu Pancasila. ${ }^{41}$ Pancasila sebagai falsafah, pandangan hidup dan ideologi kenegaraan Indonesia mengandung cita hukumnya (rechtsidee) tersendiri. Bahwa nilai-nilai Pancasila harus dipandang sebagai norma dasar bernegara (Grundnorm/ Staatsfundamentalnorm) yang menjadi sumber dari segala sumber hukum di Indonesia. ${ }^{42}$

Setiap bangsa perlu secara sungguh-sungguh menentukan identitas bangsa (national identity), tak hanya secara ekonomi dan politik tetapi juga secara hukum. Pancasila telah memberikan dasar yang kokoh bagi kemajemukan bertumbuh dan saling membangun. Pancasila harus terus kita pegang sebagai paradigma perumusan kebijakan hukum dalam masyarakat yang majemuk. la harus menjadi basis berpikir, menilai, dan mengimplementasikan segala kebijakan hukum yang akan dibuat. Terkait dengan hal ini setidaknya ada dua hal penting yang harus kita perhatikan.

Pertama, kesamaan berpikir ini tak hanya harus dimiliki oleh perumus kebijakan tetapi harus dilakukan secara menyeluruh oleh seluruh elemen pemerintahan (whole government approach). Dengan demikian, penghormatan dan perlindungan terhadap kemajemukan yang telah digariskan dalam konstitusi dan produkproduk hukum yang ada tidak hanya akan tertulis di atas kertas tapi mampu menjelma menjadi kenyataan. Paradigma yang sama harus ada pada tahap pembentuk kebijakan oleh legislatif, implementasi kebijakan oleh eksekutif, dan penegakan hukum oleh lembaga yudikatif. Suatu kebijakan hukum harus dikawal mulai dari tahap perumusan (design), penegakan (delivery), dan pengawasannya (inspection). Tanpa adanya paradigma yang sama, penghormatan dan

${ }_{41}$ Lihat Yasonna H. Laloy, dalam Backy Krisnayuda, Pancasila dan Undang-Undang: Relasi dan Transformasi Keduanya dalam Sistem Ketatanegaraan Indonesia, (Jakarta: Prenadamedia, 2016), hlm vi.

42 Yudi Latif, "Pancasila Sebagai Norma Dasar Negara: Implikasinya Terhadap Perumusan Konstitusi", Makalah Disampaikan Dalam FGD Evaluasi Dan Proyeksi Pembangunan Hukum Nasional Dalam Rangka Penyusunan Dokumen Pembangunan Hukum Nasional Tahun 2016, diselenggarakan di BPHN (9 November 2016), hlm.1. 
perlindungan terhadap kemajemukan yang telah teruang dalam beragam produk hukum di Indonesia barangkali hanya akan menjadi janji kosong yang tidak mampu mewujud dalam kenyataan.

Kedua, perlu dicatat bahwa kebijakan hukum tidak hanya harus menghormati kemajemukan tetapi juga harus mampu menjaga agar kemajemukan yang ada bersifat konstruktif dan tidak keluar dari batas-batas yang ada. Penindasan atau pemaksaan kehendak atas nama tuntutan pengakuan terhadap kemajemukan, misalnya, jelas tidak dapat dibenarkan karena mengingkari Pancasila dan hakikat dari kemajemukan itu sendiri. Terhadap tindakan-tindakan semacam ini, negara tidak perlu ragu untuk melakukan penegakan hukum sebagai bentuk konsistensinya terhadap Pancasila dan jaminan terhadap kemajemukan itu sendiri. Negara perlu mengambil perannya untuk menegaskan kembali kepada segenap elemen masyarakat mengenai kesepakatan bernegara. Di sinilah hukum menjadi penunjuk arah bagi masyarakat dan membangun secara konstruktif budaya hukum yang Pancasilais, habitat yang tepat bagi tumbuh kembangnya masyarakat yang majemuk.

Meskipun pengakuan terhadap kemajemukan ini diberikan oleh konstitusi, tetapi Paralegal yang berbasis masyarakat adat perlu diberikan pemahaman mengenai nilainilai HAM dan bagaimana memperjuangkannya dalam lingkup komunitas adat. Hal ini mengingat bahwa masih terdapat nilai-nilai dalam hukum adat yang belum selaras dengan HAM dan masih bias gender. Di beberapa komunitas adat masih pula terlihat nilai dan sanksi yang menempatkan perempuan tidak setara hak-haknya dengan laki-laki (bias gender). Sebagai contoh, dalam pelaksanaan pembagian warisan yang terjadi di NTB acapkali ditemukan adanya pelanggaran terhadap hak perempuan untuk memperoleh bagian warisan, hal ini bukan sematamata karena faktor hukum adat yang tidak mengakomodir hak perempuan, melainkan juga karena perlakuan ahli waris laki-laki yang kurang memperhatikan hak Perempuan, baik pada masyarakat Suku Samawa (Sumbawa), Mbojo (Bima) maupun Sasak. ${ }^{43}$ Praktek adat yang bias gender ini juga terjadi dalam pelaksanaan musyawarah adat. Kaum laki-laki selalu berperan sebagai pemimpin, sedangkan kaum perempuan hanya sebagai peserta. Kaum perempuan tidak berhak sebagai pemimpin dalam memimpin rapat maupun jabatan struktural dan fungsional dalam masyarakat. Besarnya peran kaum lakilaki sebagi kepala rumah tangga membawa dampak terhadap lebih besarnya perolehan hak laki-laki dalam pewarisan dibandingkan dengan kaum perempuan ${ }^{44}$.

Kondisi yang masih memerlukan penyelarasan dan pembaharuan ini direspons oleh beberapa komunitas adat di beberapa daerah sehingga kemudian telah ada pula upayaupaya untuk menyelaraskan nilai-nilai adat agar selaras dengan HAM. Di Aceh misalnya, karena dianggap bertentangan dengan hak azasi manusia (HAM), hukum Islam, dan hukum Nasional serta merendahkan harga diri manusia maka telah ditentukan beberapa sanksi atau hukuman yang tidak lagi berlaku dan dituangkan melalui penyusunan sebuah pedoman peradilan

\footnotetext{
43 BPHN, Hukum Adat Yang Melanggar Hak Asasi Perempuan Pada Masyarakat Adat Di Nusa Tenggara Barat (NTB) Dan Nusa Tenggara Timur (NTT), (Jakarta: BPHN 2006) hlm.51. Lihat juga Lebih jauh lihat Arfan Faiz Muhlizi, opcit, hlm.74-75.

44 Ibid, hlm.44.
} 
adat (guidelines). Sanksi dan hukuman tersebut diantaranya adalah: ${ }^{45}$ dimandikan dengan air kotor, ditenggelamkan ke sungai, dikeroyok/ dianiaya, dan dipukuli. Sedangkan sanksi atau hukuman yang masih berlaku dalam hukum adat aceh adalah: nasihat, peringatan, minta maaf di depan umum, ganti rugi, diusir dari gampong, pencabutan gelar adat, dikucilkan dalam pergaulan, dan diboikot. ${ }^{46}$ Dengan adanya UU Bantuan Hukum yang menganut asas keadilan dan equality before the law ini maka penyelarasan nilai dan sanksi adat dengan HAM ini sangat penting untuk bisa dilaksanakan.

\section{c. Keterampilan Mengadvokasi Masyarakat Berupa Pembelaan Dan Dukungan Terhadap Masyarakat Lemah Untuk Mendapatkan Hak-Haknya.}

Pada dasarnya pelatihan ketrampilan mengadvokasi ini dimaksudkan agar para paralegal menjadi matang dalam melakukan advokasi ${ }^{47}$. Pelatihan ini bisa difasilitasi oleh OBH maupun Pemerintah atau Pemerintah Daerah dengan penguatan pada substansi pemahaman hukum formil dan materiil, teknik komunikasi, negosiasi, mediasi serta alternaif lainnya.

Agar advokasi hukum dan HAM dapat berjalan dengan baik, diperlukan keserasian dalam hubungan antara beberapa faktor, yaitu substansi hukum atau peraturan itu sendiri ${ }^{48}$, mentalitas petugas yang menegakan hukum ${ }^{49}$, fasilitas yang diharapkan untuk mendukung pelaksanaan hukum ${ }^{50}$, serta kesadaran hukum, kepatuhan hukum dan perilaku warga masyarakat. Salah satu upaya yang saat ini tengah dilakukan adalah dengan lebih banyak membuka akses bagi publik untuk memberi masukan bagi perumusan maupun evaluasi kebijakan. ${ }^{51}$ Jika di masa lalu partisipasi publik identik dengan kegiatan-kegiatan rapat atau

45 MAA, Pedoman Peradilan Adat Di Aceh: Untuk Peradilan Adat Yang Adil Dan Akuntabel, Proyek Bappenas UNDP, hlm. 27. diakses dari http://ind.adatjustice.org/wp-content/ uploads/ publikasi/ Buku\% 20Pedoman\% 20Peradilan. Pdf. Lihat juga Lebih jauh lihat Arfan Faiz Muhlizi, opcit, hlm.74-75.

46 Ibid.

47 Pada mulanya kata "advokasi" muncul dalam pengertian pembelaan terhadap berbagai kasus-kasus Hukum yang ada dalam masyarakat. Padahal kerja advokasi tidak sekedar melakukan pembelaan dalam wilayah hukum tapi juga kebijakan. Advokasi diartikan sebagai upaya pendekatan terhadap orang lain yang dianggap mempunyai pengaruh terhadap keberhasilan suatu program atau kegiatan yang dilaksanakan. Oleh karena itu yang menjadi sasaran advokasi adalah para pemimpin atau pengambil kebijakan (policy makers) atau pembuat keputusan (decision makers) baik di institusi pemerintah maupun swasta. Advokasi adalah suatu alat untuk melaksanakan suatu tindakan (aksi), merupakan ikhtiar politis yang memerlukan perencanaan yang cermat untuk dapat mencapai tujuan yang diinginkan. Diperlukan langkah-langkah sistematis dengan melibatkan masyarakat yang akan diwakili. Advokasi secara umum dibagi menjadi dua, advokasi litigasi dan advokasi nonlitigasi.

48 Kadangkala ada ketidakserasian antara hukum positif baik secara vertikal maupun horisontal, serta antara hukum positif dengan hukum yang hidup di masyarakat.

49 Hal ini antara lain mencakup hakim, polisi, jaksa, pembela, petugas pemasyarakatan, dan seterusnya. Apabila peraturan perundang-undangan sudah baik, tetapi mental penegak hukum kurang baik, maka akan terjadi gangguan pada sistem penegakan hukum.

50 Jika peraturan perundang-undangan sudah baik dan juga mentalitas penegaknya baik, akan tetapi fasilitas kurang memadai (dalam ukuran tertentu), maka penegakan hukum tidak akan berjalan dengan semestinya.

51 Advokasi Litigasi pada dasarnya telah diatur dalam beberapa peraturan perundang-undangan seperti: UndangUndang Nomor 16 Tahun 2011 tentang Bantuan Hukum, Undang-undang Nomor 18 Tahun 2003 tentang Advokat, dan Undang-Undang Nomor 8 Tahun 1981 tentang Hukum Acara Pidana (KUHAP). Sedangkan Advokasi Non Litigasi pada dasarnya telah diberikan ruang dalam banyak peraturan perundang-undangan yang mengatur mengenai partisipasi publik, dan bahkan menjadi agenda penting pemerintahan saat ini dalam rangka membangun tata kelola pemerintah yang bersih, efektif, demokratis dan terpercaya. Agenda ini tertuang menjadi lima agenda yang lebih spesifik, salah satunya adalah "meningkatkan partisipasi publik dalam proses 
forum-forum tatap muka, maka saat ini tengah terus dikembangkan cara-cara konsultasi publik yang lebih inovatif dengan daya jangkau yang lebih luas.

\section{Penutup}

Dari uraian di atas dapat disimpulkan bahwa: pertama, Paralegal yang tumbuh dari komunitas adat tetapi belum berafiliasi dengan OBH Terakreditasi pun perlu lebih mendapatkan perhatian dan pengakuan atas eksistensinya. Perhatian dan pengakuan terhadap paralegal yang lahir dari komunitas adat ini telah memiliki landasan politik dan konstitusi sebagaimana dicantumkan secara tegas dalam Pasal 18B ayat (1) dan (2), Pasal 28D ayat (1), (2), dan (3), Pasal 28E ayat (2), Pasal 28I huruf (2), serta Pasal 29 ayat (2) UUD NRI 1945. Pada tataran di bawah konstitusi, komitmen ini nyata terlihat dalam beberapa undang-undang seperti UndangUndang Nomor 39 Tahun 1999 tentang Hak Asasi Manusia, Undang-Undang Nomor 40 Tahun 2008 tentang Penghapusan Diskriminasi Ras dan Etnis, Undang-Undang Nomor 12 Tahun 2006 tentang Kewarganegaraan, serta Undang-Undang Nomor 12 tahun 2005 tentang Pengesahan International Covenant on Civil and Political Rights (Kovenan Internasional tentang Hak-Hak Sipil dan Politik). Begitu juga dalam hal pembentukan peraturan perundang-undangan,
Pasal 6 Undang-Undang Nomor 12 Tahun 2011 juga mencantumkan asas kenusantaraan dan asas bhinneka tunggal ika sebagai materi muatan yang harus dicerminkan oleh setiap peraturan perundang-undangan. Meski telah mendapatkan landasan hukum yang kuat, tetapi paralegal yang tumbuh dalam komunitas masyarakat adat tetapi belum terdaftar pada $\mathrm{OBH}$, dapat saling berinteraksi maka Paralegal yang tumbuh dalam komunitas masyarakat adat belum terdaftar pada pemberi bantuan hukum $(\mathrm{OBH})$ harus berafiliasi dengan $\mathrm{OBH}$ Terakreditasi sehingga output kegiatannya jadi lebih jelas. Selain itu, jika paralegal komunitas tersebut berafiliasi dengan $\mathrm{OBH}$ Terakreditasi maka paralegal tersebut dapat mengakses dana bantuan hukum yang diberikan melalui $\mathrm{OBH}$ tersebut. Oleh karena itu maka $\mathrm{OBH}$ Terakreditasi perlu terus didorong agar terusmenerus untuk merekrut paralegal komunitas adat, atau terus-menerus membuka diri jika terdapat paralegal yang tumbuh dari komunitas adat berkeinginan untuk berafiliasi. Dengan demikian maka jangkauan bantuan hukum menjadi lebih luas bagi masyarakat adat melalui jalur non litigasi.

Kedua, Paralegal perlu memperoleh pelatihan yang memadai agar memiliki standar kemampuan yang baik untuk memberikan

pengambilan kebijakan publik dengan meningkatkan peran aktif masyarakat dalam pengambilan kebijakan publik dan pengelolaan badan publik yang baik". Perhatian terhadap isu partisipasi publik menunjukkan perkembangan yang cukup signifikan. Komitmen mendasar terhadap hal ini pertama-tama dapat dilihat dalam Pasal 28 Undang-Undang Dasar Negara Republik Indonesia Tahun 1945 yang memberikan jaminan hak menyampaikan pendapat, berserikat, berkumpul, menyatakan pendapat secara lisan dan tulisan. Berbagai peraturan perundang-undangan juga lahir dan turut membangun iklim keterbukaan dan partisipasi publik yang lebih baik di antaranya Undang-Undang Nomor 14 Tahun 2008 tentang Keterbukaan Informasi Publik, UndangUndang Nomor 40 Tahun 1999 tentang Pers, Undang-Undang Nomor 32 Tahun 2002 tentang Penyiaran. Bahkan untuk mendorong partisipasi publik dalam pembentukan peraturan perundang-undangan, Undang-Undang Nomor 12 Tahun 2011 tentang Pembentukan Peraturan Perundang-undangan memuat satu bab khusus yaitu Bab XI terkait partisipasi masyarakat yang menyatakan bahwa masyarakat berhak memberikan masukan secara lisan dan/atau tertulis dalam Pembentukan Peraturan Perundang-Undangan. 
bantuan hukum non litigasi, ${ }^{52}$ serta dapat memahami dan mematuhi kode etik internal Pemberi Bantuan Hukum dimana paralegal tersebut terdaftar; dan standar bantuan hukum berdasarkan Undang-Undang Nomor 16 Tahun 2011 tentang Bantuan Hukum. ${ }^{53}$ Beberapa kompetensi dasar yang perlu dimiliki oleh Paralegal tersebut adalah: pertama, kemampuan memahami kondisi wilayah dan kelompok-kelompok kepentingan dalam masyarakat; kedua, kemampuan melakukan penguatan masyarakat dalam memperjuangkan hak asasi manusia, dan hak-hak lain yang dilindungi oleh hukum; dan ketiga, keterampilan mengadvokasi masyarakat berupa pembelaan dan dukungan terhadap masyarakat lemah untuk mendapatkan hak-haknya. ${ }^{54}$

\section{DAFTAR PUSTAKA}

\section{Buku}

Dworkin, Ronald. Legal Research, (Daedalus: Spring,1973)

Hadikusuma, Hilman. Pengantar Antropology Hukum, (Bandung: Citra Aditya Bakti, 1992)

Hamzah, Andi. Perkembangan Hukum Pidana Dalam Era Globalisasi, Asosiasi Pengajar Hukum Pidana dan Kriminologi Indonesia, (Jakarta: Perum Percetakan Negara RI, 2008)

Hartono, Sunaryati. Bhinneka Tunggal Ika sebagai Asas Hukum bagi Pembangunan Hukum Nasional, (Bandung: Penerbit Citra Aditya Bakti, 2006)

Ihromi, T.O. (ed.), Antropology dan Hukum, (Jakarta: Yayasan Obor Indonesia, 1984)
Koesno, Muhammad. Musyawarah dalam Miriam Budiardjo (Ed), Masalah Kenegaraan, (Jakarta: tanpa penerbit, 1971).

Laloy, Yasonna H. Pengantar dalam Backy Krisnayuda, Pancasila dan Undang-Undang: Relasi dan Transformasi Keduanya dalam Sistem Ketatanegaraan Indonesia, (Jakarta: Prenadamedia, 2016),

Lev, Daniel S. Hukum dan Politik di Indonesia, (Jakarta: LP3ES, 1990)

Lubis, Todung Mulya. Bantuan Hukum dan Kemiskinan Struktural, (Jakarta: LP3ES, 1986)

Ohorela H.M.G. dan H. Aminuddin Salle, Penyelesaian Sengketa Melalui Arbitrase pada Masyarakat di Pedesaan di Sulawesi Selatan, dalam Felix O. Soebagjo dan Erman Rajagukguk (ed.), Arbitrase di Indonesia, (Jakarta: Ghalia Indonesia, 1995)

Rahmadi, Takdir dan Achmad Romsan, Teknik Mediasi Tradisional Dalam Masyarakat Adat Minangkabau, Sumatera Barat dan Masayarakat Adat di Dataran Tinggi, Sumatera Selatan, (Jakarta: Indonesia Center For Environmental Law (ICEL), The Ford Foundation 1997-1998).

Sapardjaja, Komariah Emong. Ajaran Sifat Melawan Hukum Materiel Dalam Hukum Pidana Indonesia Studi Kasus tentang Penerapan dan Perkembangannya Dalam Yurisprudensi, (Bandung: PT Alumni, 2002)

Soedarto, Hukum dan Hukum Pidana, (Bandung: PT Alumni, 1983)

\section{Makalah/Artikel/Prosiding/Hasil Penelitian}

Benda-Beckmann, Franz von, "Changing Legal Pluralism in Indonesia, $\mathrm{VI}$ th International Symposium Commission on Folk Law and Legal Pluralism", Ottawa, (1990)

Hasan, Ahmadi. "Penyelesaian Sengketa Hukum Berdasarkan Adat Badamai Pada Masyarakat Banjar dalam Kerangka Sistem Hukum Nasional", Disertasi pada Program Doktor Ilmu Hukum

52 Lebih jauh mengenai hal ini lihat Pasal 6 ayat (1), Pasal 7 ayat (1), dan Pasal 9 ayat (1) Peraturan Menteri Hukum dan HAM Nomor 1 Tahun 2018 tentang Paralegal Dalam Pemberian Bantuan Hukum, yang menyatakan bahwa Paralegal berhak untuk berpartisipasi dalam sesi pelatihan untuk meningkatkan kualifikasi dan keahlian mereka sebagai pelaksana penyedia bantuan hukum. Pelatihan paralegal dapat diselenggarakan oleh Pemberi Bantuan Hukum; Universitas; Organisasi masyarakat yang menyediakan bantuan hukum; dan/atau Institusi pemerintah, setelah mereka mengajukan proposal pelatihan dan telah disetujui oleh BPHN.

53 Lihat Pasal 15 Peraturan Menteri Hukum dan HAM Nomor 1 Tahun 2018 tentang Paralegal Dalam Pemberian Bantuan Hukum.

54 Lihat Pasal 6 Peraturan Menteri Hukum dan HAM Nomor 1 Tahun 2018 tentang Paralegal Dalam Pemberian Bantuan Hukum 
Pasasarjana Fakultas Hukum Universitas Islam Indonesia, Yogyakarta, Tahun 2007.

Latif, Yudi. "Pancasila Sebagai Norma Dasar Negara: Implikasinya Terhadap Perumusan Konstitusi", Makalah Disampaikan Dalam FGD Evaluasi Dan Proyeksi Pembangunan Hukum Nasional Dalam Rangka Penyusunan Dokumen Pembangunan Hukum Nasional Tahun 2016, diselenggarakan di BPHN (9 November 2016)

Makinara, Ihdi Karim. "Pengaruh Bantuan Hukum Terhadap Masyarakat Miskin", dalam Jurnal Rechtsvinding Volume 2 Nomor 1, (April Tahun 2013)

Muhlizi, Arfan Faiz. Bantuan Hukum Melalui Mekanisme Nonlitigasi Sebagai Saluran Penguatan Peradilan Informal Bagi Masyarakat
Adat, dalam Jurnal Rechtsvinding Volume 2 Nomor 1, April Tahun 2013

\section{Internet}

Bappenas, Masyarakat Adat di Indonesia: Menuju Perlindungan Sosial Yang Inklusif, Cetakan I Desember 2013, Diakses dari https://www. bappenas.go.id/files/7014/2889/4255/ Masyarakat_Adat__di_Indonesia- Menuju_ Perlindungan_Sosial_yang_Inklusif.pdf

Qur'ani, Hamalatul. Mindset Advokat tentang Probono Harus Diubah, Hukum Online, 24 September 2018, diakses dari https:// www.hukumonline.com/ berita/ baca/ It5ba8e7248fb66/ i-mindset-i-advokatindonesia-tentang-pro-bono-harus-diubah 
"Halaman ini dikosongkan" 